\title{
A The Description Of The Ninth Grade Junior High School Students' Cognitive Ability In Completing The Two Linear Variables Equation Viewed From Solo Taxonomy
}

\author{
Sesilia Intan Kusuma Nuringtyas ${ }^{1}$, Tri Nova Hasti Yunianta ${ }^{2}$ \\ 1,2 Universitas Kristen Satya Wacana: 202015023@student.uksw.edu
}

\begin{abstract}
This research is qualitative descriptive research which aims to describe ninth grade students' cognitive abilities in solving the problem of two-variable linear equations (PLDV) through Solo Taxonomy. The techniques of data collection were tests, interviews, and documentation. The credibility of the data in this research is guaranteed using the triangulation method. The results of this research, based on five levels of Solo Taxonomy, show the students' understanding and problem-solving abilities based on their cognitive abilities. In this case, the subject of high cognitive ability (DW) was able to reach five levels of the Solo Taxonomy and the subject of moderate cognitive ability (RN) was able to reach three levels of the Solo Taxonomy. So that it can be said that the two subjects were able to understand and solve the problem of two-variable linear equations (PLDV). The subject of low cognitive ability (AB) was able to reach one level of Solo Taxonomy so that it can be said that the subject has not been able to understand and solve PLDV problems.
\end{abstract}

Keywords: Cognitive Ability; Problem Solving; Two-Variable Linear Equations (PLDV), Solo Taxonomy.

\section{INTRODUCTION}

Problem-solving is part of the thinking process that uses knowledge and skills to answer unanswered questions. The results of solving problems done by different people are likely to get different results depending on the type of solved problem. (Suhaeni, Tandiayuk, \& Rizal, 2016). One subject that is often used in problem-solving is algebraic questions which are usually displayed in the form of equations. One of the algebraic materials at the junior high school level is the two-variable linear equations (PLDV), the PLDV problem used in this research relates to daily life. In reality, many students experience difficulties in solving PLDV problems. The Solo Taxonomy model can use in knowing the difficulties in solving problems.

The Solo Taxonomy model is one of the easiest tools to find out, compile, and determine students' ability to solve problems. (Lipianto et al., 2013) Solo taxonomy has been proven effective as a planning tool and curricula development based on the cognitive characteristics of the students. Solo Taxonomy in test questions can help to find out how students solve the math problem and as a practical evaluation tool to measure the quality of responses to a problem based on the complexity of students' understanding or answers to the problem given and also designed to measure students' answers. (Meriyana, Tandiayuk, \& Paloloang, 2016). Solo Taxonomy can describe the students' performance when handling a problem and describe the level of students' understanding through five student response levels. Not all students get all five response levels. Five levels of thinking response based on Solo Taxonomy are PreStructural, Uni-Structural, Multi-Structural, Relational, and Extended Abstract. The higher the 
level of questions students can work on, the higher the ability to understand and solve the problems given. Conversely, the lower the level of questions students can work on, the lower the ability to understand and solve the problem given.

Based on previous research, many studies have been conducted on increasing students' cognitive abilities in solving problems of two-variables linear equations (Christiyanto, Sulandra, \& Rahardi, 2018; Irfan, 2018; Rismawati, Irawan, \& Susanto, 2017; Ristiani, Ratu, \& Yunianta, 2015) as well as research that reviews Solo Taxonomy (Azizah, 2015; Ghati, 2018; Lipianto et al., 2013; Manibuy, Mardiyana, \& Saputro, 2014; Pesona, 2018; Rosyida Ekawati dkk, 2013; Tarigan, 2014; Widyawati, Afifah, \& Resbiantoro, 2018). However, there are no studies describing the cognitive abilities of students in solving the problem of two-variables linear equations viewed from Solo Taxonomy

Based on previous research, the novelty of this research lies in the description of students' cognitive abilities in solving the problem of two-variable linear equations viewed from Solo Taxonomy. So, this research aims to describe the cognitive abilities of students in solving the problem of two-variable linear equations in terms of Solo Taxonomy

\section{THE RESEARCH METHODS}

The type of research used is qualitative descriptive research. Data collected are in the form of images, writings, and words both oral and written. The subjects in this research were students of the ninth grade of Pangudi Luhur Junior High School who possessed high, moderate, and low cognitive abilities taken using purposive sampling technique. The flowchart of this research is illustrated in Figure 1.

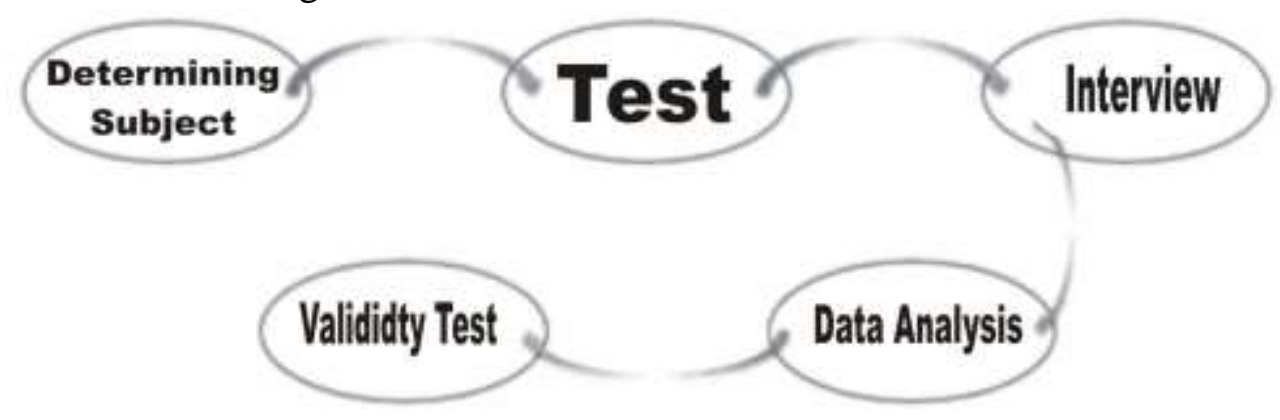

Figure 1. Research's Flowchart

In the test, the students were given questions that have been measured based on the level of thinking of the Solo Taxonomy. The test questions given had gone through the validation stage. After the test, the subjects were interviewed to find further problems where information about students' answers could be obtained. After getting the data, the researcher conducted data analysis and tested the validity of the data. In data analysis, students' answers were then classified as students' cognitive abilities based on Solo Taxonomy. The classification criteria can be seen in Table 1. 
Table 1. The Cognitive Ability Classification Levels

Based on Taxonomy Solo

\begin{tabular}{lc}
\multicolumn{1}{c}{ Student Answers } & Level of Cognitive Ability Students \\
\hline Do not answer, Incorrect Answer & Pre-Structural \\
\hline $\begin{array}{l}\text { Based on one data or information relevant to the } \\
\text { question }\end{array}$ & Uni-Structural \\
\hline $\begin{array}{l}\text { Two or more separate information contained in the } \\
\text { questions }\end{array}$ & Relational \\
\hline $\begin{array}{l}\text { Show some understanding of the concept and link the } \\
\text { data or concept using data to obtain information }\end{array}$ & Extended Abstract \\
\hline $\begin{array}{l}\text { Based on information from the question, can make } \\
\text { generalizations, and can connect the problem into } \\
\text { other situations. }\end{array}$ &
\end{tabular}

The first data collection techniques in this research were tests, interviews, and documentation. The main instruments in this research are the researchers themselves and the additional instruments (written tests). The specification of the written test indicators can be seen in Table 2.

Table 2. The Specification of the Written Test Indicators

\begin{tabular}{cccc}
\hline \multirow{2}{*}{ Basic Competency } & $\begin{array}{c}\text { Taxonomy Solo } \\
\text { Levels }\end{array}$ & $\begin{array}{c}\text { Indicators of Students' } \\
\text { Abilities in Solo } \\
\text { Taxonomy }\end{array}$ & Problem Indicator \\
\hline
\end{tabular}

Students obtain pieces of information that are

Pre-Structural separated from one another which is not organized and has no meaning.
Problem-solving questions are given related to PLDV. The students write down the information on the question.

\begin{tabular}{ll}
\hline & $\begin{array}{l}\text { Students can make real and } \\
\text { simple connections but the }\end{array}$ Questions to differentiate \\
Uni-Structural & $\begin{array}{l}\text { meaning cannot bes, coefficients, and } \\
\text { understood }\end{array}$
\end{tabular}

Resolve problems related to the system of twovariable linear equations

\begin{tabular}{|c|c|c|}
\hline Multi-Structural & $\begin{array}{l}\text { Students are able to make a } \\
\text { number of connections that } \\
\text { are separate from each } \\
\text { other so that they have not } \\
\text { formed a comprehensive } \\
\text { understanding. }\end{array}$ & $\begin{array}{l}\text { Questions about mathematical } \\
\text { forms/equations for problems } \\
\text { that have been given. }\end{array}$ \\
\hline Relational & $\begin{array}{l}\text { Students are able to } \\
\text { understand the meaning of } \\
\text { the relationship among } \\
\text { parts with the overall } \\
\text { information. }\end{array}$ & $\begin{array}{l}\text { Questions about } \\
\text { price/amount. }\end{array}$ \\
\hline
\end{tabular}




\section{Students make \\ Extended Abstract relationships not only in terms of what is given but types of high-level questions. also from outside sources.}

At the interview stage, the researchers used interview guidelines that contain interview questions items to explore further information related to the matters not written on the answer sheet. The implementation of this interview was flexible where the researchers asked the questions spontaneously to get more complete data. Interview guidelines can be seen in Table 3.

Table 3. Interview Guidelines

\begin{tabular}{ccl}
\hline No & Level of Solo Taxonomy & \multicolumn{1}{c}{ Indicators } \\
\hline 1 & Pre-Structural & Describe the written information. \\
\hline 2 & Uni-Structural & $\begin{array}{l}\text { Describe the variables, coefficients, and constants that have been } \\
\text { written. }\end{array}$ \\
\hline 3 & Multi-Structural & $\begin{array}{l}\text { Describes the form / mathematical equations of the problem that } \\
\text { has been given. }\end{array}$ \\
\hline 4 & Relational & $\begin{array}{l}\text { Explain how to solve problems based on information that has been } \\
\text { written. }\end{array}$ \\
\hline 5 & Extended Abstract & $\begin{array}{l}\text { Describes a different solution or problem-solving and provide } \\
\text { reasons. }\end{array}$ \\
\hline
\end{tabular}

In this research, there are four ways to analyze the data, namely data reduction, data presentation, data verification, and data validity testing. Triangulation is used in this research. The triangulation used is method triangulation by checking the obtained data through test, interviews, and documentation.

\section{THE RESULTS OF THE RESEARCH AND THE DISCUSSION}

This research describes the cognitive abilities of the ninth grade junior high school students in solving PLDV problems in terms of Solo Taxonomy. Before determining the subjects of the research, the researchers made validated question indicators adjusted to the basic competencies in the two-variable linear equation material. Then, the researchers obtained three subjects through the steps written and explained in the research method. The three subjects were named (initials) DW as the subject with high cognitive ability, $\mathrm{RN}$ as the subject with moderate cognitive ability, and $\mathrm{AB}$ as the subject with low cognitive ability. The following are the results and analysis of the three subjects based on test results and interviews. 


\section{A. The Results of DW's Answers (High Ability)}

DW can work on PLDV problems based on Solo Taxonomy level of problem 1 and 2. This can be seen from the test results and interviews as follows:
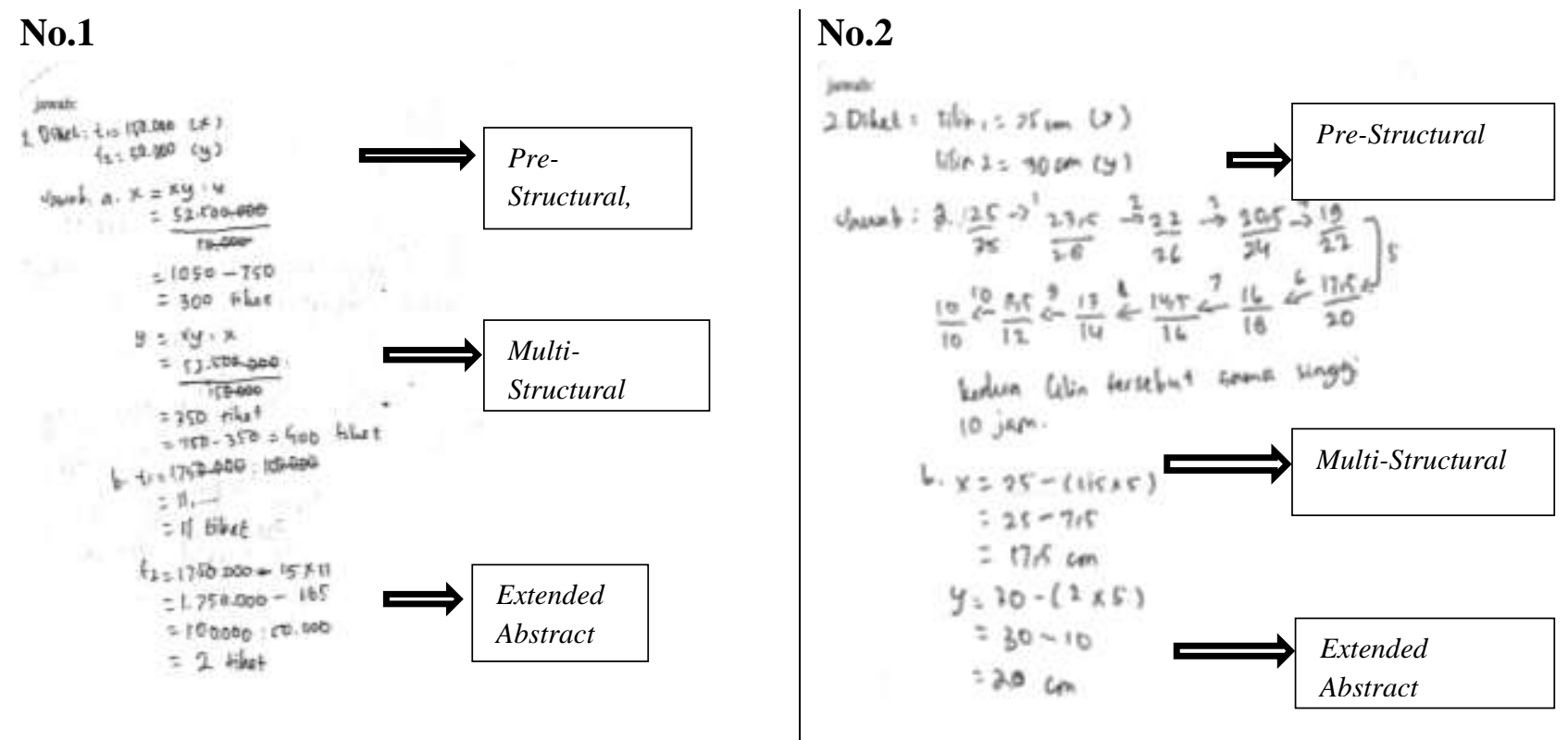

\section{Figure 2. Results of DW's Answers in Resolving Problems 1 and 2}

Following are the DW's stages in resolving PLDV problems
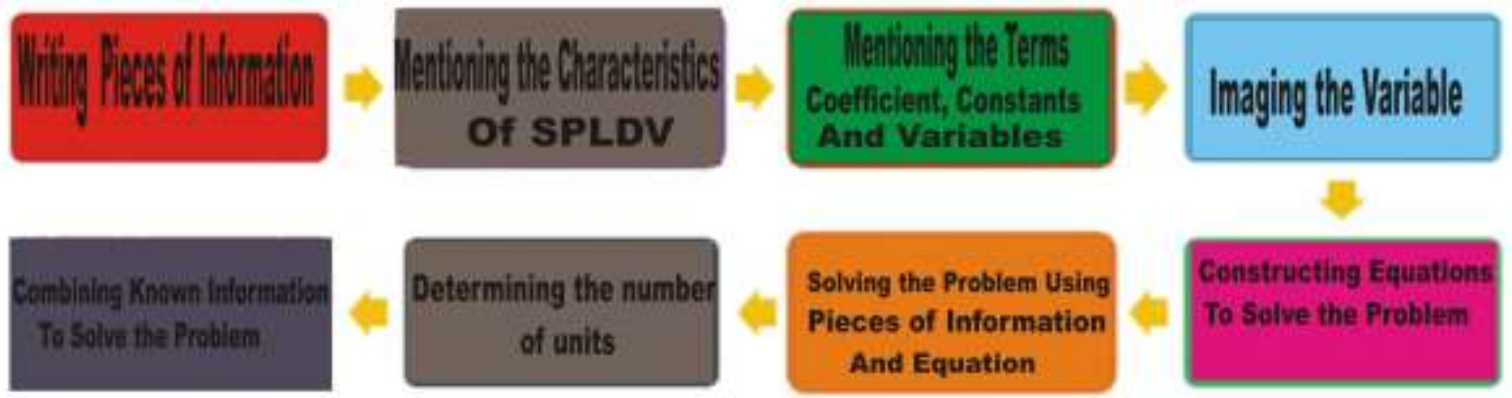

Figure 3. DW's Stages in Resolving PLDV Problems

Based on Figure 2, it can be seen that DW wrote information known in the question and can mention the characteristics of the PLDV problems in which composed of variables, constants, and coefficients (pre-structural). DW assumed the variables in the problem, symbolized the variables $\mathrm{x}$ and $\mathrm{y}$, and specified which were the variables, coefficients, and constants (uni-structural). DW did not write an equation but symbolized $\mathrm{x}$ and $\mathrm{y}$ and can answer the question with a multi-structural example. DW could solve the PLDV problems by using what is known in the problems and could find the number of units (relational). DW was able to combine separate pieces of information and combine what was already known in his own way to answer the questions at this level (extended abstract). It could be concluded that DW can 
solve the problems by fulfilling the 5 levels of Solo Taxonomy, namely the Pre-Structural, Union-Structural, Multi-Structural, Relational, and Extended Abstract. This can also be seen in the following interview passage of each level.

\section{Pre-structural Level}

Here are DW's statements in solving question number 1 and 2 at the Pre-Structural level during the interview.

P: What do you know about the system of linear equations of two variables (SPLDV)?

S: In SPLDV there are terms, variables, constants, coefficients.

It can be seen from the answer that DW has fulfilled the pre-structural level.

\section{Uni-Structural Level}

Here are DW's statements in solving question number 1 and 2 at the Uni-Structural level during the interview.

$\mathrm{P}$ : Here, you didn't write the equation. If this (designating paper with the equation $+\mathrm{y}=$ $750->x+y-750=0$, this equation is made by the researcher, because in the answer, DW can suppose the variable $\mathrm{x}$ and $\mathrm{y}$ but did not write the equation) which one is the variable?

$\mathrm{S}: \quad$ The variable is $\mathrm{x}$ and $\mathrm{y}$

$\mathrm{P}$ : Which one is the coefficient?

$\mathrm{S}$ : $\quad$ Emmm ...the coefficient is 1 (designating coefficients at $\mathrm{x}$ and $\mathrm{y}$ )

$\mathrm{P}$ : Which one is the constant?

S: $\quad 750$

P: Which one is the term? Do you know?

S: Term? I don't know

The excerpts of the following interview

$\mathrm{P}$ : For this matter, what is the gold supposed to be?

S: $\quad$ It is supposedly $\mathrm{x}$.

$\mathrm{P}$ : The silver one?

S It is supposedly y.

It can be seen from the DW's answers in Figure 2 and the results of the interview that DW has fulfilled the Uni-structural level.

\section{Multi-Structural Level}

It can be seen from the answers in Figure 2 that indirectly DW has fulfilled the Multi-structural level.

\section{The Relational Level}

The following are DW's statements in solving question number 1 and 2 at the Relational level during the interview. 
$\mathrm{P}$ The first one, the question is the number of gold and silver class audiences; could you explain how to answer it?

$\mathrm{S}$ First, the amount of $\mathrm{x}$ and $\mathrm{y}(52,500,000)$ is this.

$\mathrm{S}$ Then to find the first ticket(x), the number of $\mathrm{x}$ and $\mathrm{y}$ is divided by the price of the second ticket $(y=50,000)$. After that, I subtracted it by the number of tickets sold that day (750).

$\mathrm{P}$ Then to look for $\mathrm{Y}$, is it the same?

S To find the first $y$ is the same (52,000 (xy): 150,000 (x)), but the number of this ticket (750 tickets) minus this ticket

$\mathrm{P} \quad$ Do you mean the known numbers?

S Yes (350 tickets)

Here are the excerpts of DW in solving question number 2

P: Next is the candle, how can you explain this?

S: It was subtracted, it was subtracted by the average height, so there it is at 10

P: Until this (up and down) is the same or not?

S: Yes, until this (top and bottom) is the same, 25-1.5.

P: It means that you didn't use the elimination and substitution method, right?

Do you even know what the elimination and substitution methods are? Have you ever been taught about that?

S: $\quad$ Yes, I have

P: For example, if the equation is known, can the elimination and substitution be used?

S: Yes, it can

It can be seen from the answer in Figure 2 and the results of the interview that DW has fulfilled the Relational level.

\section{The Extended Abstract Level}

The following are DW's statements in solving question number 1 and 2 at the extended abstract level during the interview.

P: Now, how did you solve the "b"?

S: $\quad$ Firstly, Adi's money is divided by the price of the gold ticket, the answer is 11, only 11. For the second one, I counted 2 tickets.

P: $\quad$ This amount of money can be used to buy 11 tickets (gold) and 2 tickets (silver). Well, there are other possibilities besides this, right? For example, 10 tickets and 1 ticket, 9 tickets and 3 tickets. Do you think so?

S: $\quad$ Yes, I do 
Next is an excerpt of the DW interview in solving question number 2

S: $\quad$ Yes, that's right

P: What about question number to $b$ ?

S: Looking for the height of the candle every hour. The height of the first candle is subtracted by the average height of the candle per hour which mean 5 hours. It means it should be multiplied by 5 . The height is then subtracted by this result, hence 17.5.

P: $\quad$ That answer is for five hours, right? How about if you are asked to determine the height per hour?. It means there will be 1 hour, 2 hours, 3 hours, 4 hours, and 5 hours. If you can answer the 5 hours one, what about for 4 hours?

S: $\quad$ The 5 hours is replaced by 4 hours (in 1.5 hours multiplication)

P: Are you sure your answer is correct?

S: $\quad$ Yes, I am.

It can be seen from the answers in Figure 2 and the results of the interview that DW has fulfilled the extended abstract level.

\section{B. Results of RN's Answer (Medium Ability)}

RN, although incomplete, can do the PLDV problems based on Solo Taxonomy number 1 and 2. It can be seen from the results of the tests and interviews as follows.

No. 1

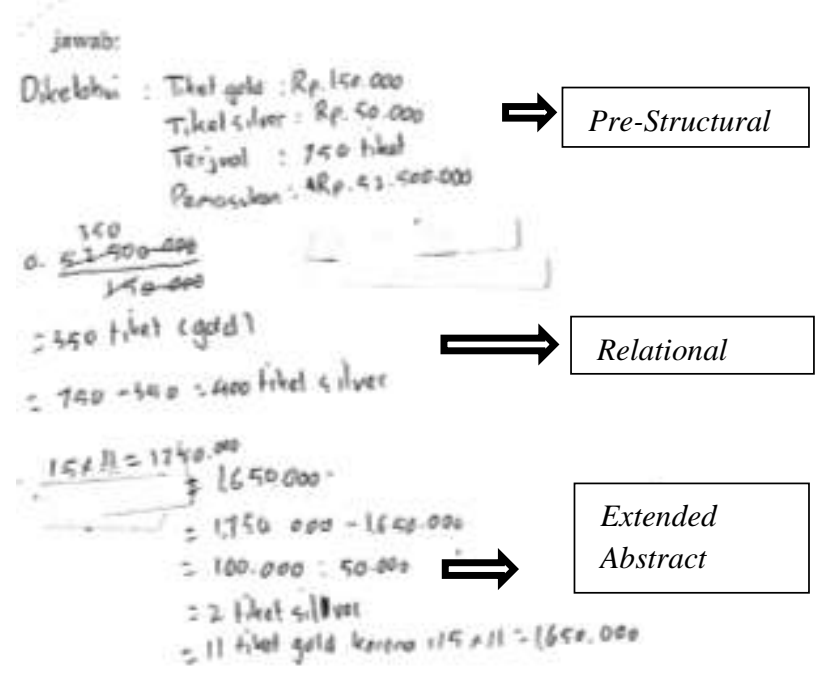

No. 2

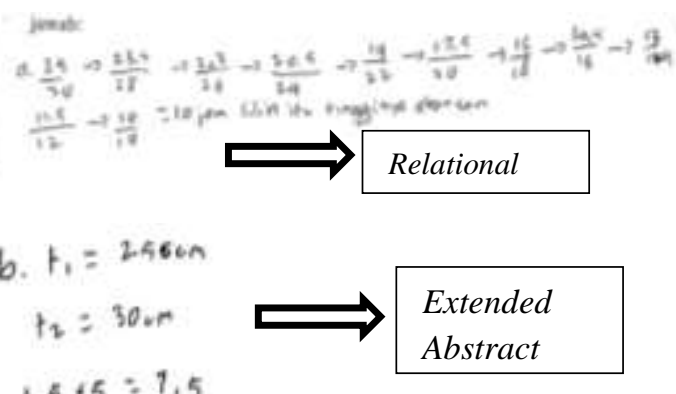

$1,5,5=1,5$

${ }^{2}$ का $15=100 \mathrm{~m}$

$t_{1}=25 \cdot 7,5$

$=17,5 \mathrm{~cm}$

$12=30-10 \mathrm{~s}$

$=200 \mathrm{n}$

Figure 4. The Results of RN's Answers in Solving Problems Number 1 and 2 
The following are the stages of solving PLDV problems
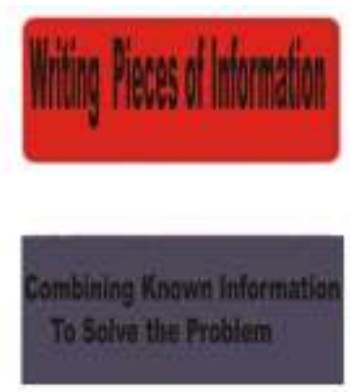
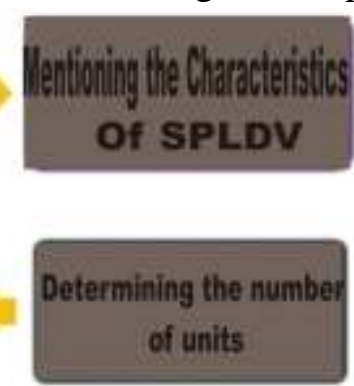

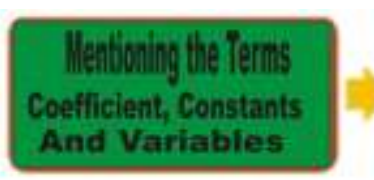

Solving the Problem Using

Pieces of Information And Equation
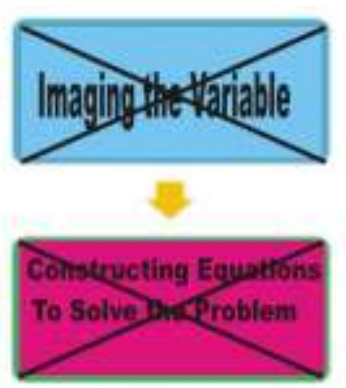

Figure 5. RN's Stages in Solving PLDV Problems

Based on Figure 4, the subject could write down the information in the problem and could mention the characteristics of PLDV problems in which there are terms, variables, constants, and coefficients (pre-structural). The subject was not been able to substitute the variables in the problem. The subject can answer which are the terms, coefficients, and constants but were not correct. RN did not consider the variable and did not write the equation on the question of this level. The subject could solve the PLDV problem by using the information found in the problem and could find the number of units (relational). The subject was able to combine separate pieces of information and combine what was already known in his own way to answer questions at this level (extended abstract). It can be concluded that RN can solve the problem by fulfilling 4 levels of Solo Taxonomy, namely pre-structural, relational, and extended abstract level. The subject can meet the pre-structural, relational, and extended abstract level but cannot meet the other levels, namely the unstructured and multi-structural level. This can also be seen in the following interview passage at each level.

\section{Pre-structural Level}

Here are the RN's statements in solving question number 1 and 2 at the Pre-structural level during the interview.

Q: Do you know what linear equation of two variables is?

S: Equations followed by terms, variables, constants, and coefficients

It can be seen from the answers in Figure 4 and the results of the interview that RN has fulfilled the pre-structural level.

\section{Uni-Structural Level}

It can be seen from the RN's answer in Figure 4. It appears that RN has not fulfilled the Uni-structural level. The subject did not include the variables in the question. the interview by the researchers is as follows:

P: You didn't write the equation here. (pointing to the paper with the equation $\mathrm{x}+\mathrm{y}=750->x+y-750=0$ ), which one is the term?

$\mathrm{S}$ : This one (pointing at $\mathrm{x}$ and $\mathrm{y}$ )

$\mathrm{P}: \quad$ Coefficient?

S: $\quad$ This one (pointing at number 0)

P: The variable? 


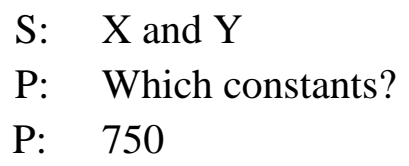

It can be seen that RN has not yet fulfilled the Uni-Structural level.

\section{Multi-Structural Level}

It can be seen from the answers in Figure 4 that $\mathrm{RN}$ does not specify the variable. $\mathrm{RN}$ also does not write down the equation. It means that RN has not met the Multi-Structural level.

\section{Level Relational}

The following is an excerpt from the interview with $\mathrm{RN}$ in solving question number 1 at the relational level

P: Now try to explain how did you find out each gold and silver class audience.

S: The 52,500,000 income is divided by the price of the gold ticket which is 150,000 . The result is 350 tickets. The remaining 750 tickets are subtracted by gold tickets. The result is 400 for silver tickets.

Here is an excerpt of RN's interview in solving question number 2

P: How did you solve question number 2?

P: $\quad$ I did it by sorting it, for example, the 25 and $30 \mathrm{~cm}$. If the $25 \mathrm{~cm}$ candle melted 1.5 $\mathrm{cm}$ in 1 hour and the $30 \mathrm{~cm}$ candle melted in 2 hours. I sorted them. I subtracted the $25 \mathrm{~cm}$ and $30 \mathrm{~cm}$ candle by 1.5 and 2 until the candle is lit at the same time for 10 hours

P: Do you know the substitution and elimination method? Have you ever been taught about them?

S: $\quad$ Yes, I have

P: Do you think this problem can be solved by that method?

S: $\quad$ Sure

It can be seen from RN's answer in Figure 4 and the results of the interview that the subject has met the relational level.

\section{Extended Abstract Level}

The following is the statement in solving question number 1 at the extended abstract level during the interview.

P: Now, how did you find this b?

S: $\quad$ The amount of Adi's money is $1,750,000$. Eleven gold tickets approximately $1,750,000$. If 11 multiplied by 150.000 you will get 1.650 .000 , then, $175,000,000$ - 1650000 is 100,000 . If the price of the silver ticket is 50,000 , it means that it can get 2 silver tickets.

Here is the excerpt of an interview in solving number 2.

P: What about the broblem? 
S: The candles have to be lit for five hours. The height of the first candle is $25 \mathrm{~cm}$ and the second is $30 \mathrm{~cm}$. then I multiplied 1.5 by 5 hours. The $2 \mathrm{~cm}$ multiplied by 5 is 10 hours. Then the $25 \mathrm{~cm}$ is subtracted by 7.5 while the $30 \mathrm{~cm}$ is subtracted by 10. The result is 17.5 and $20 \mathrm{~cm}$

P: Alright, what if it is for 4 hours, which calculation should be changed?

S: $\quad$ The height? the melting average per hour is multiplied by 4 hours

P: Okay, are you sure?

S: $\quad$ Yes, I am

It can be seen from the answers in Figure 4 and the results of the interview that $\mathrm{RN}$ has fulfilled the extended abstract level.

\section{The Result of AB's Answers (Low Ability)}

The subject can do the PLDV problems based on Solo Taxonomy number 1 although incorrectly. It can be seen from the results of the tests and interviews as follows:

No. 1
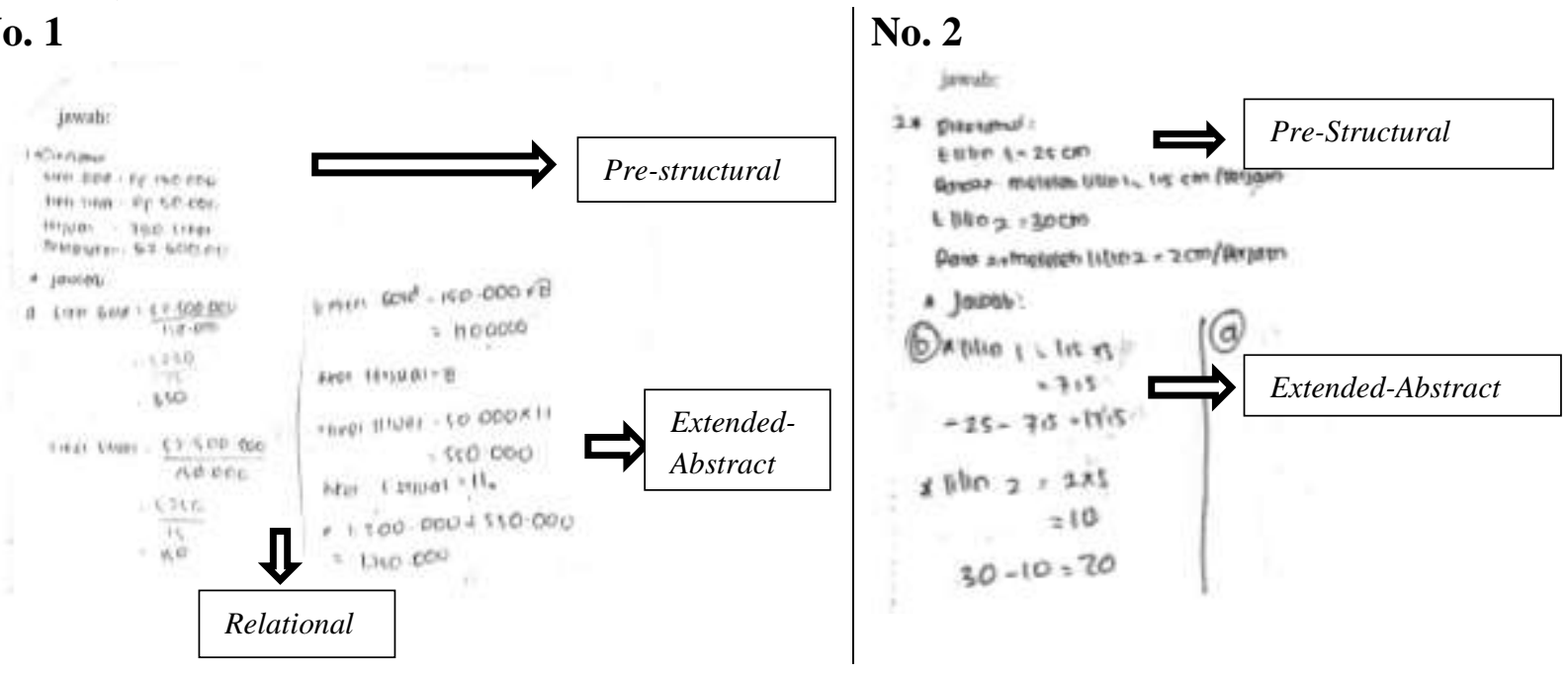

Figure 6. The Result of AB's Answers in Solving Problems Number 1 and 2

Here are the AB'S stages in solving PLDV problems:
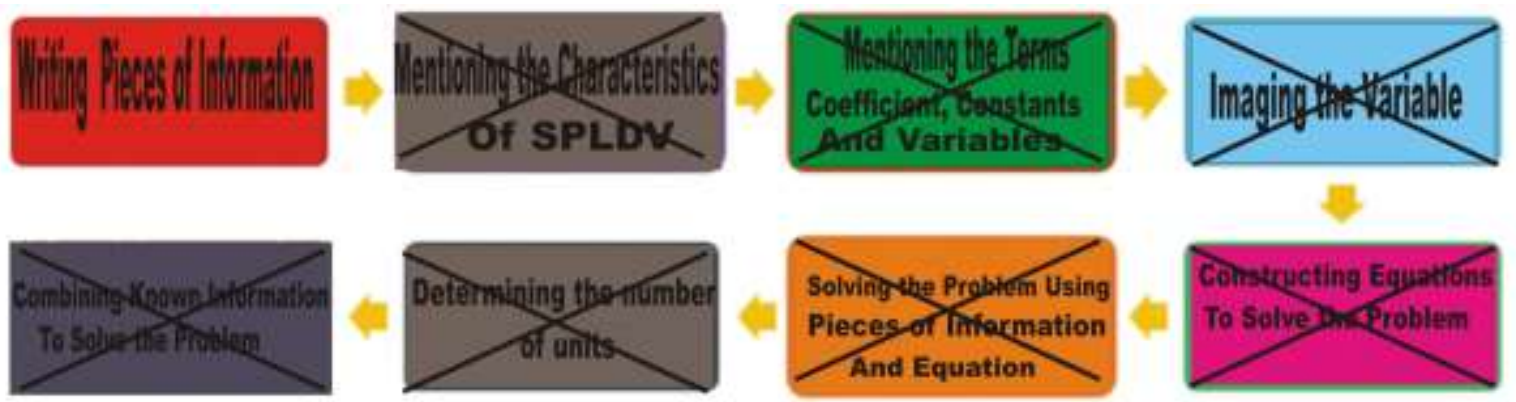

Figure 7. The AB'S Stages in Solving PLDV Problems

Based on Figure 6, AB can write down the information of the problem and can specify features characterizes the PLDV problem in which there are terms, variables, constants, and 
coefficients (Pre-Structural). AB has not been able to transform the variables in the problem. The subject cannot answer which are variables, terms, coefficients, and constants. The subject does not consider the variable and does not write the equation on the question of this level. Subject AB has not been able to resolve the PLDV problem and has not been able to find the number of units. Subject $A B$ uses existing pieces of information to answer questions at this level, but only roughly, subject $A B$ is also not sure of the answer. The description concludes that subject $\mathrm{AB}$ can solve the problem by fulfilling 1 level of Solo Taxonomy which is the PreStructural level only. This can also be seen in the interview.

\section{Pre-structural Level}

Here are excerpts of the interview with $\mathrm{AB}$ in solving question number 1 and 2 at the prestructural level.

Q: $\quad$ Do you know what system of linear equations of two variables (SPLDV) is?

S: $\quad$ To find the value of $x$ and $y$

P: What are their characteristics?

S: $\quad$ Having terms, variables, constants, and coefficients

It can be seen from the answer in Figure 6 and the results of the interview that AB has fulfilled the pre-structural level.

\section{Uni-Structural Level}

It can be seen from the answer in Figure 6 that $A B$ has not yet met the structural level. $\mathrm{AB}$ did not consider the variables in the question and also when interviewed by the researcher as follows:

P: Here, you did not write the equation. Look at this (pointing to the paper with the equation $\mathrm{x}+\mathrm{y}=750->x+y-750=0$ ), which one is the term?

S: $\quad x$ and $y$

P: So, which one is the term?

S: I don't know

P: Which one is the constant?

S: I don't know

P: Coefficient of $x$ ?

S: I don't know

It appears that $\mathrm{AB}$ has not met the Uni-Structural level.

\section{Level Multi-Structural}

It can be seen from the answers in Figure 6 where AB did not specify the variable and did not write the equation. So it can be concluded that $\mathrm{AB}$ has not met the Multi-Structural level.

\section{Relational Level}

The following is the AB's statement in solving question number 1 at the relational level during the interview. 
Q: How did you answer this question?

S: You know the gold ticket costs 150. If you want to find the number of each audience, the ticket for gold is $52,500,000$ divided by 150,000 the result is 350 . The tickets for silver is $52,500,000$ divided by 150,000 , the result is 150 .

The quote the following interview

P: $\quad$ You used this method for no.1. Do you know the elimination and substitution method? Have you ever been taught?

S: $\quad$ Yes, I have but I forgot

P: For example, if the equation is known, can it be done by eliminating substitution?

S: $\quad$...... I think so (doubtful)

It can be seen from the answers in Figure 6 and the results of the interview that $A B$ has not met the relational level.

\section{Level Extended Abstract}

The following are AB's statement in solving question number 1 at the extended abstract level during the interview

P: If Adi has 1,750,000, how many gold and silver tickets can he buy?

S: $\quad$ The gold ticket is 150 times 8

P: $\quad$ How come it's 8 ? Why did you write 8 and 11 here?

S: $\quad$ Emmm ... I just guessed

Here is an excerpt from the $\mathrm{AB}$ interview in completing question number 2

$\mathrm{P}$ : $\quad$ How did you find out the height of the first and the second candle?

S: $\quad$ The first candle's height is $25 \mathrm{~cm}$, and on average it melts by $1.5 \mathrm{~cm}$ per hour. First, 1.5 times 5 is 7.5 then $25-7.5$ the result is 17.5

P : $\quad$ The height of the first candle per 5 hours?

S: $\quad$ Yes, for the second candle, 2 times 5is $10.30-10$ is 20

$\mathrm{P}: \quad$ So, is there any other possibility?

S: $\quad$...... (Silent)

$\mathrm{P}$ : $\quad$ Are you sure about your answer?

S: $\quad$ Somewhat sure

P : $\quad$ Not $100 \%$ sure?

S: $\quad$ No

It can be seen from the answers in Figure 6 and the results of the interview that AB has not been able to meet the extended-abstract level.

\section{Discussion}

On the Solo Taxonomy, the first level is pre-structural. At this level, the students only get pieces of information that are separated from one another which are unorganized and have no meaning. The three subjects with high, medium and low abilities were able to meet this level. All three subjects are able to write down the information on the question and mention the characteristics of the PLDV problem. 
The second level in Solo Taxonomy is uni-structural. At this level, the students can make real and simple connections but the meaning is not clear. At this level, high ability subjects are able to assume variables and able to show which one are the variables, coefficients, and constants appropriately. Medium and low category subjects have not been able to assume variables and have not been precise in showing which are variables, coefficients, constants, and terms.

The third level in Solo Taxonomy is the multi-structural level. At this level, the students are able to make a number of connections although they are still separate from each other so as not to form a comprehensive understanding. At this level, high, medium and low category subjects do not make the equation but the high category subject can assume variables that can be used to answer the problem. This is in line with the research of Pasandaran (2016) at the high multi-structural level, the subject reasons algorithmically.

The fourth level in Solo Taxonomy is the relational level. At this level, students are able to understand the meaning of the relationship among parts with the overall information. At this level, the subject in the high category is able to solve the problem using the information found on the question. The subject is in the high category and is able to find the number of units while the low category subject cannot answer the problem and unable to find the number of units.

The fifth level in Solo Taxonomy is the extended abstract level. At this level, the students make connections not only in matters given but also from outside sources. At this level, the high ability subject is able to solve the PLDV problem. The high ability subject is able to write down possible answers to the questions at this level and be sure on the answers he is working on. The low category subject can write down possible answers but is hesitant and answers with approximate. He is also unsure of what he is doing.

The result of this research indicates that PLDV problems that have been compiled based on the five levels of Solo Taxonomy can show students' comprehension and problem-solving abilities based on their cognitive abilities, in this case, the subject with high cognitive abilities and subject with medium cognitive abilities can be said to understand and solve PLDV problems while the subject with low cognitive abilities is unable to understand and solve PLDV problems.

The above description is in line with Ruslan Laisow's (2013) research, Elita Safitri (2016) Rian Ika (2017), and Elpin Rambo (2017) who say that highly capable students can solve problems up to the extended abstract stage. It is different from the research of Imi Yuslianti (2016), Ruslan Laisow (2013), Putri (2013), and Rian Ika (2017) who say that students with moderate abilities can solve structural and multi-structural level problems. In this research, the moderate category subject cannot solve the structural and multi-structural level questions but can complete the relational and extended abstract level questions; this is in line with Elpin Rambo's (2017) research. In contrast to Muhamad Ilman Nafi'an's (2015) which stated that low category subjects reached multi-structural levels, while in this research, low category subject could only reach pre-structural level only. In contrast to previous studies which showed that subjects with moderate cognitive abilities could reach the relational and extended abstract levels at the solo taxonomy level, they could not meet the uni-structural and multi-structural level. 
The result of this research also shows that PLDV can be done in various ways, not only by elimination and substitution methods. This research is expected to explain the cognitive abilities of students in understanding and solving PLDV problems as well as providing an illustration for readers to use questions compiled based on Solo Taxonomy in measuring students' comprehension and problem-solving abilities.

\section{CONCLUSION AND SUGGESTION}

Based on the results of the analysis and discussion, it can be concluded that the subject of high cognitive ability can solve the problem by fulfilling the 5 levels of Solo Taxonomy, namely the pre-structural, uni-structural, multi-structural, relational, and extended abstract level, so that the subject is able to understand and solve PLDV problems. The subject in the medium ability category can solve the problems by fulfilling the 3 levels of Solo Taxonomy, namely the prestructural, union-relational, and extended abstract level so that it can be said that the subject is able to understand and solve PLDV problems. Subjects with low cognitive abilities can solve the problem by fulfilling 1 level of Solo Taxonomy, namely the pre-structural level so that it can be said that the subject has not been able to understand and solve PLDV problems.

Based on the conclusion, the researchers suggest the teachers train the students using problem-solving type questions in order for them to teach the five level of Solo Taxonomy. Future researchers who intend to conduct similar research should focus on developing a variety of PLDV problem-solving type questions and material based on Solo Taxonomy.

\section{REFERENCES}

Azizah, F. R. (2015). Analisis Kemampuan Pemecahan Masalah Matematika Berdasarkan Taksonomi Solo pada Sub Pokok Bahasan Balok Siswa Kelas VIII-H SMP, 1-241.

Christiyanto, D. Y., Sulandra, I. M., \& Rahardi, R. (2018). Proses Berfikir Kritis Siswa Reflektif dalam Menyelesaikan Masalah Matematika Pada Materi Sistem Persamaan Linier Dua Variabel. Jurnal Pendidikan : Teori, Penelitian, Dan Pengembangan, 3(10), $1-12$.

Ghati, E. W. (2018). Dengan Model Pembelajaran Berbasis Masalah Berdasarkan Taksonomi Solo, 5(2), 209-216.

Irfan, M. (2018). Proses Berpikir Siswa Yang Mengalami Math-Anxiety Dalam Menyelesaikan Masalah Sistem Persamaan Linier Dua Variabel. Kalamatika, 3(1), 27-38.

Lipianto, D., Budiarto, M. T., Matematika, J., Surabaya, U. N., Matematika, J., \& Surabaya, U. N. (2013). Analisis kesalahan siswa dalam menyelesakan soal yang berhubungan dengan persegi dan persegipanjang berdasarkan Taksonomi Solo plus pada kelas vii. Mathedunesa, 2(1).

Manibuy, R., Mardiyana, \& Saputro, D. R. S. (2014). Analisis Kesalahan Siswa Dalam Menyelesaikan Soal Persamaan Kuadrat Berdasarkan Taksonomi Solopada Kelas X SMA Negeri 1 Plus Di Kabupaten Nabire - Papua. Jurnal Elektronik Pembelajaran Matematika, 2(9), 933-945. 
Meriyana, Tandiayuk, M. B., \& Paloloang, B. (2016). Profil Berpikir Siswa Kelas VIII SMP Dalam Menyelesaikan Soal Cerita Aljabar Berpandu PadaTaksonomi Solo Ditinjau Dari Tingkat Motivasi Belajar Matematik. Aksioma : Jurnal Pendidikan Matematika, 5(1), 113.

Pesona, R. I. dan T. N. H. Y. (2018). Deskripsi Kemampuan Matematika Siswa Dalam Pemecahan Masalah Sistem Persamaan Linear Dua Variabel Berdasarkan Level. Jurnal Genta Mulia, 9(1), 99-109.

Rismawati, M., Irawan, E. B., \& Susanto, H. (2017). Struktur Koneksi Matematis Siswa Kelas X Pada Materi Sistem Persamaan Linier Dua Variabel. Jurnal Pendidikan: Teori, Penelitian, Dan Pengembangan, 2(4), 1-5.

Ristiani, M., Ratu, N., \& Yunianta, T. N. H. (2015). Strategi Pemecahan Masalah Dalam Menyelesaikan Soal Cerita Pada Materi Persamaan Dan Pertidaksamaan Linier Satu Variabel. Satya Widya, 31(1), 8-16.

Rosyida Ekawati dkk. (2013). Studi Respon Siswa Dalam Menyelesaikan Soal Pemecahan Masalah Matematika Berdasarkan Taksonomi Solo. Journal of Mathematics Education Research, 2(2), 103.

Suhaeni, Tandiayuk, M. B., \& Rizal, M. (2016). Analisis Pemecahan Masalah Siswa Berkemampuan Matematika Tinggi Dalam Menyelesaikan Masalah Sistem Persamaan Linear Dua Variabel Dikelas VII SMP Negeri 12 Palu. Aksioma, 5(1).

Tarigan, D. (2014). Taksonomi Solo dalam Analisis Kesalahan Menyelesaikan Soal Geometri Bagi Mahasiswa PGSD. Jurnal Pengabdian Kepada Masyarakat, 20(75), 34-39.

Widyawati, A., Afifah, D. S. N., \& Resbiantoro, G. (2018). Analisis Kesalahan Siswa dalam Memecahkan Masalah Lingkaran Berdasarkan Taksonomi Solo pada Kelas VIII. Jurnal Pendidikan Matematika Dan Sains, VI(1), 1-9. 